ISBN 978-93-84422-85-1

11th International Conference on Chemical, Agricultural, Biological and Environmental Sciences

(CABES-2018)

April 17-18, 2018 Kyoto (Japan)

\title{
Response of Lymphocite in Model Animal Suppelemented with Lactic Acid Bacteria from Dangke by Protection Test of Escherichia coli
}

\author{
Fatmawati Nur ${ }^{1 *}$, Sriwahyuni ${ }^{1}$, Cut Muthiadin ${ }^{1}, \operatorname{Hafsan}^{1}$ and Mochammad Hatta ${ }^{2}$ \\ ${ }^{1 *}$ Department Biology, Faculty of Science and Technology, Alauddin Islamic State University, Indonesia \\ ${ }^{2}$ Department Microbiology, Faculty of Medical, Hasanuddin University, Indonesia
}

\begin{abstract}
Lactic Acid Bacteria is a gram-positive bacteria that can produce lactic acid that has potential as a probiotic. The mechanism of action is by the production of antimicrobial substances, nutritional competition and space adhesion, and immune stimulation. The objective of this study was to investigate the response of lymphocytes of mice (Mus musculus) with Lactic Acid Bacteria supplementation from dangke Enterococcus faecium and Lactobacillus plantarum which were challenged with EPEC (Enteropathogenic Escherichia coli). The method used was supplementation using lactic acid bacteria orally with 6 treatement ie group A (negative control, without treatment), group B (Enterococcus faecium), group C (Enterococcus faecium + EPEC), group D (Lactobacillus. plantarum), group $E$ (L. plantarum + EPEC), and group $F$ (positive control, EPEC administration). Lactic Acid Bacteria Enterococcus faecium and Lactobacillus plantarum isolated from dangke have the ability to increase the immune system of mice caused by EPEC (Enteropathogenic Escherichia coli).
\end{abstract}

Keywords: Enterococcus faecium, Lactic Acid Bacteria, Lactobacillus plantarum, Lymphocytes

\section{Introduction}

Lactic Acid Bacteria (LAB) affect the intestinal ecosystem by stimulating the immune mechanism of the intestinal mucosa as well as stimulating non-immune mechanisms through antagonism and competition with potential pathogens. In general, bacteria often used in the manufacture of probiotics are lactic acid bacteria species Lactobacillus sp., Bifidobacterium $\mathrm{sp}^{2}$

In former studies, we have obtained two species of Lactobacillus plantarum and Lactobacillus fermentum from traditional food known as "dangke" from buffalo milk, and derived from cow milk, which is resulted that isolates of lactic acid bacteria detected were genera of Lactobacillus with criteria Gram positive, rod shaped, non-motile and could survive at $\mathrm{pH} 2$.

Some research results indicate that $\mathrm{LAB}$ consumed along with fermented milk products can improve host immunity. Increased immunity is due to increased number of leukocyte cells, increased cytokine production, increased phagocytic activity, on the other hand Schiffrin et al. (1995) found that there was no increase in the number of leukocytes after the consumption of lactic acid bacteria through fermented milk but found increased phagocytosis to Escherichia coli in vitro. Interaction between non-pathogenic bacteria Lactobacillus johnsonii, Lb. casei and Escherichia coli with leucocyte cells in vitro showed that these three strains of bacteria can increase the proliferation of leukocyte cells. Most proliferation is caused by interaction with Lb. Johnsonii.

Therefore, in this study we conducted to identify the effect of Lactic acid bacteria from dangke isolate Enterococcus faecium and Lactobacillus plantarum into Mice (Mus musculus) ICR which given EPEC (Enteropathogenic Escherichia coli) bacteria.

${ }^{2}$ Fajardo, Paula et al. "Effects of Feeding of Two Potentially Probiotic Preparations from Lactic Acid Bacteria on the 
Performance and Faecal Microflora of Broiler Chickens." The Scientific World Journal 2012 (2012): 562635. PMC. Web. 6 Apr. 2018.

${ }^{3}$ Nur, Fatmawati, Hafsan, Andi Wahdiniar. Isolation of Lactic Acid Bacteria Potentially Probiotics In Dangke, Traditional Food from Buffalo Milk in Curio Enrekang Regency. Vol 3, No. 1, Juni 2015, pp. 60-65 .

${ }^{4}$ Nur, Fatmawati, Hatta, M., Natzir, Rosdiana \& Djide, M.N. "Isolation of Lactic Acid Bacteria as a Potential Probiotic in Dangke, A Traditional Food from Enrekang, Indonesia." International Journal of Sciences: Basic and Applied Research (IJSBAR) [Online], 35.1 (2017): 19-27. Web. 6 Apr. 2018

${ }^{5}$ Schiffrin , E.J., F. Rochat, H. Link-Amster, J.M. Aeschlimann dan A. Donnet-Hughes. "Immunomodulation of human blood cells following the ingestion of lactic acid bacteria". J. Dairy Sci. (1995): p. 78: 491-497.

\section{Methods}

\subsection{Adaptation of mice}

Test animals used in this study were male ICR mice with an average body weight of 18-33 grams and age 23 months obtained from Biopharmaceutical Laboratory of Hasanuddin University Faculty of Pharmacy.

\subsection{Preparation of Lactic Acid Bacteria Suspension}

The preparation of LAB suspension was done by transferring 1 ose of LAB isolate into the deMan Rogosa Sharpe Broth (MRSB) media then homogenized, then piping $1 \mathrm{ml}$ of the isolate solution into $9 \mathrm{ml}$ of aquadest and homogenized then calculating the amount of BAL suspension to reach the population of $10^{8} \mathrm{CFU} / \mathrm{ml}$ with using a spectrophotometer. Testing was administered orally, giving the drug in the form of suspension and solution to the test animal by using a hypodermic needle with a blunt end (ball shape, sonde)

\subsection{Treatment of Animal Experiments}

Mice (Mus musculus) were divided into 6 treatment groups. Group A (negative control) is normal mice that only given aquadest, group $\mathrm{B}$ that is mice given LAB A, group $\mathrm{C}$ that is mice given LAB A + EPEC, group D that is given $\mathrm{LAB} B$, group $\mathrm{E}$ that is mice given $\mathrm{LAB} \mathrm{B}+\mathrm{EPEC}$, and group $\mathrm{F}$ (positive control) ie mice infected with EPEC. During the experiment, all groups of mice were fed standard feed rations. (note: LAB $\mathrm{A}=$ Enterococcus faecium and LAB B = Lactobacillus plantarum).

Given of LAB done for three full weeks, ie from day 1 to 21 , orally via sonde. The LAB given is $0.2 \mathrm{ml}$ with a population of $108 \mathrm{CFU} / \mathrm{ml}$ according to Mc's Farland standard $\left(0.5 \times 10^{8} \mathrm{CFU} / \mathrm{ml}\right)$. EPEC infection was performed with a population of $10^{6} \mathrm{CFU} / \mathrm{ml}$ of $0.2 \mathrm{ml}$ per day for 7 days (days 8 to 14), orally using sonde. For the analysis of variables, a hematological test (full blood test) was performed on the mice's blood taken on the last day of the trial (day 21) to see the number of WBC (White Blood Cell) and lymphocytes from each treatment group.

\subsection{Observation of Mouse Survivality}

Observe the survival of mice by looking at the mice that survived until the last day of observation (day 21). Calculation of survival rate of mice is by dividing the number of mice that live during a certain time interval with the initial population number, multiplied $100 \%$.

\section{Results}

After treat mice with BAL supplementation from dangke for 7 days, the mice were then tested with Escherichia coli. Induction was performed orally for 7 days. Observations were made from the first day of treatment until the 21st day by looking at the number of mice (Mus musculus) that survive. Based on the results of the study it is known that there were deaths in some groups of mice treatment and in the positive group. This can be seen in Table 1 . 
TABLE I: Survive Percentage of Mice

\begin{tabular}{|l|c|c|}
\hline TREATMENT & Number of motility & \% survive (for 21days) \\
& 0 & $\mathbf{1 0 0}$ \\
Negative control (A) & 0 & $\mathbf{1 0 0}$ \\
BAL A (B) & 2 & 60 \\
\hline BAL A + EPEC (C) & 1 & 80 \\
\hline BAL B (D) & 1 & 80 \\
\hline BAL B + EPEC (E) & 2 & 60 \\
\hline Positive control /EPEC (F) & & \\
\hline
\end{tabular}

For the analysis of variables, a complete blood test was conducted to determine how the effect of BAL supplementation on immune responses of mice (Mus musculus) that had been challenged with Escherichia coli with parameters to be observed were WBC (White Blood Cell) and Lymphocytes. Result of observation of hematology test with parameter of WBC (White Blood Cell / White Blood Cell) can be seen in Table below (table 2)

TABLE II: Results of Hematology Test of Blood Mice White Blood Cell Parameters

\begin{tabular}{|l|l|l|l|l|}
\hline Parameter & Treatment & Amount WBC & Normal Range & Notes \\
\hline \multirow{3}{*}{$\begin{array}{l}\text { White } \\
\text { Blood }\end{array}$} & $\mathrm{A}$ & $3.6 \times 10^{3} / \mu \mathrm{L}$ & & Increase \\
\cline { 2 - 3 } & $\mathrm{B}$ & $5.1 \times 10^{3} / \mu \mathrm{L}$ & \multirow{4}{*}{$0.05-0.52$} & Increase \\
\cline { 2 - 3 } & $\mathrm{C}$ & $7.3 \times 10^{3} / \mu \mathrm{L}$ & & \\
\cline { 2 - 3 } & $\mathrm{D}$ & $9.8 \times 10^{3} / \mu \mathrm{L}$ & & Increase \\
\cline { 2 - 3 } \cline { 2 - 2 } & $\mathrm{E}$ & $7.1 \times 10^{3} / \mu \mathrm{L}$ & & Increase \\
\cline { 2 - 3 } & $\mathrm{F}$ & $1.3 \times 10^{3} / \mu \mathrm{L}$ & & Increase \\
\hline
\end{tabular}

TABLES III: Results of Hematology Test of Blood Mice Lymphocite Cell Parameters

\begin{tabular}{|c|c|c|c|c|}
\hline Parameter & Treatment & \% Lymphocite & Normal Range & Notes \\
\hline \multirow{6}{*}{ Lymphocite } & $\mathrm{A}$ & 92.9 & \multirow{6}{*}{$20-50 \%$} & Increase \\
\hline & B & $5.1 \times 10^{3} / \mu \mathrm{L}$ & & Increase \\
\hline & $\mathrm{C}$ & $7.3 \times 10^{3} / \mu \mathrm{L}$ & & Increase \\
\hline & $\mathrm{D}$ & $9.8 \times 10^{3} / \mu \mathrm{L}$ & & Increase \\
\hline & $\mathrm{E}$ & $7.1 \times 10^{3} / \mu \mathrm{L}$ & & Increase \\
\hline & $\mathrm{F}$ & $1.3 \times 10^{3} / \mu \mathrm{L}$ & & Increase \\
\hline
\end{tabular}

\section{Discussions}

The purpose of two isolates LAB is to examine the antidiare capability of BAL from dangke to the survival ability of mice (Mus musculus) which is challenged with one of Escherichia coli (EPEC) bacteria strain. These two LABs are expected to control bacterial pathogens in the gastrointestinal tract after infection with EPEC. Where according to Surono, it is known that EPEC is a bacterial pathogen causes diarrhea. EPEC attaches to the intestinal mucosa and causes cell structure changes, then invades through the mucosal cells 1.

Research result which percentage of survival of mice of each treatment showed that treatment group $\mathrm{C}$ was mice treated with Enterococcus faecium + EPEC and group F which was positive control ie mice treated with EPEC infection from the first day until the 21 st day had the lowest survival percentage of $60 \%$ with the number of deaths 2 mice.

Then, in Lactobacillus plantarum (D) and Lactobacillus plantarum + EPEC (E) treatment group had survival percentage $80 \%$ with mortality of 1 mice each. While the negative control treatment group (A) and Enterococcus faecium (B) were the group with the highest survival percentage that was $100 \%$ with the number of mice mortality did not exist, because the group was group without treatment and giving LAB non EPEC so

\footnotetext{
${ }^{6}$ Surono, Ingrid S. Probiotics: Fermented Milk and Health. Jakarta: Food and Beverage Entrepreneurs Foundation throughout Indonesia, 2004.
} 
that all process experienced as long as the observations are normal and do not suffer any interference from Escherichia coli bacteria.

In the hematological test (Table 2) on the blood of each group of mice, it was found that in the negative control group (A), the number of WBC (White Blood Cell) consisting of lymphocytes, granulocytes and MID (Minimum Inhibitory Dilution) was normal. This is because group A is a group without treatment.

In the group Enterococcus faecium (B) and Lactobacillus plantarum (D), the number of white blood cells, especially lymphocytes has increased while MID and granulocytes are normal. This increase is influenced by the LAB administration against group B as mentioned by Astawan (2011) that the administration of LAB affects the immunomodulatory properties of increasing the number of lymphocyte cells in spleen cells.

In the group Enterococcus faecium + EPEC (C) and Lactobacillus plantarum + EPEC (E), an increase in white blood cells, lymphocytes and granulocytes. As explained by Rahmawati, that an increase in granulocytes shows that pathogen infection occurs in a person resulting in an immune response by activating granulocytes consisting of neutrophils that function in defense against microbial invasion through phagocytosis 2 . While the decline in lymphocytes can be quite dangerous and indicates that a person is susceptible to infection.

\section{Conclusions}

Lactic Acid Bcteria Enterococcus faecium and Lactobacillus plantarum isolated from dangke have the ability to increase the immune system of mice caused by EPEC (Enteropathogenic Escherichia coli).

\section{References}

[1] Fajardo, Paula et al. "Effects of Feeding of Two Potentially Probiotic Preparations from Lactic Acid Bacteria on the Performance and Faecal Microflora of Broiler Chickens.” The Scientific World Journal 2012 (2012): 562635. PMC. Web. 6 Apr. 2018.

[2] Nur, Fatmawati, Hafsan, Andi Wahdiniar. Isolation of Lactic Acid Bacteria Potentially Probiotics In Dangke, Traditional Food from Buffalo Milk in Curio Enrekang Regency. Vol 3, No. 1, Juni 2015, pp. 60-65 .

[3] Nur, Fatmawati, Hatta, M., Natzir, Rosdiana \& Djide, M.N. "Isolation of Lactic Acid Bacteria as a Potential Probiotic in Dangke, A Traditional Food from Enrekang, Indonesia." International Journal of Sciences: Basic and Applied Research (IJSBAR) [Online], 35.1 (2017): 19-27. Web. 6 Apr. 2018

[4] Schiffrin , E.J., F. Rochat, H. Link-Amster, J.M. Aeschlimann.,A.DonnetHughes. "Immunomodulation of humanblood cells following the ingestion of lactic acid bacteria". J. Dairy Sci. (1995): p. 78: 491-497.

[5] Surono, Ingrid S. Probiotics: Fermented Milk and Health. Jakarta: Food and Beverage Entrepreneurs Foundation throughout Indonesia, 2004.

[6] Rachmawati, Fitri. Antidiarrheal Effects of Probiotic Composition On Diarrhea-Induced Mice. Thesis.Surabaya: Universitas Airlangga Press, 2016.

\footnotetext{
${ }^{7}$ Rachmawati, Fitri. Antidiarrheal Effects of Probiotic Composition On Diarrhea-Induced Mice. Thesis.Surabaya: Universitas Airlangga Press, 2016.
} 